ISSN: $2354-1431$

http://tckh.daihoctantrao.edu.vn/

\title{
Nghiên cứu mô hình xử lý nước suối Tà Vải tỉnh Hà Giang bằng công nghệ màng lọc kết hợp vật liệu lọc đa năng để cấp nước phục vụ cho sinh hoạt
}

\author{
Đặng Xuân Thường ${ }^{a}$, Luu Thị Anh Tho ${ }^{a}$, Lê Văn Thạch ${ }^{a}$, Luơng Thị Hoa ${ }^{a}$, Duơng Văn Đang ${ }^{a}$ \\ a Viện Kỹ thuật và Công nghệ Môi truờng - Liên hiệp các hội Khoa học và kỹ thuật Việt Nam
}

\section{Article info}

Recieved: 05/7/2017

Accepted:

03/8/2017

Keywords:

Stream water;

Membrane filter;

Ta Vai;

Integrated filter materials.

\begin{abstract}
Clean water is a basic necessity for daily life. Clean water helps people maintain their daily lives in case of domestic activities. If using unclean water, it will be harmful to the health because water is the medium that transports chemicals and bacteria, viruses, parasites causing diseases that are not visible to the naked eyes. According to statistics, Our country still has many places where the quality of water supply is not ensured for daily life, especially in mountainous, frontier areas and places where the terrain is difficult and lacks of facilities. The water used for living in the northwestern region in general and the Ta Vai stream's basin in Ha Giang province in particular is taken from rivers and streams that have not been treated or have been processed but the water quality is not guaranteed for living. Therefore, a study on the construction of the treatment model of Ta Vai spring water in Ha Giang province by using membrane technology combined with integrated filter materials for water supply is essential. The research shows that the water treatment model in Ta Vai stream by using membrane technology combined with integrated filter materials has completely treated water as reaching the quality of QCVN 02: 2009 / BYT - National technical regulation on domestic water quality.
\end{abstract}

\section{I. Đặt vấn đề}

Hiện nay tại các khu vực nông thôn miền núi vùng Tây Bắc nói chung và vùng lưu vực suối Tà Vải, tỉnh Hà Giang nói riêng tình trạng nước để cấp cho sinh hoạt không đảm bảo chất lượng là vấn đề đang được quan tâm, việc sử dụng nguồn nước không đảm bảo chất lượng sẽ gây ảnh hưởng đến chất lượng cuộc sống của người dân nơi đây, vì nước là môi trường trung gian chuyển tải các chất hóa học và các loại vi khuẩn, vi rút, ký sinh trùng gây bệnh mà mắt thường không nhìn thấy được. Những nguy cơ sức khỏe mà người dân đang phải đối mặt là những bệnh tật có liên quan đến điều kiện môi trường nước sinh hoạt bị ô nhiễm. Tại lưu vực suối Tà Vải thì nguồn cung cấp nước sinh hoạt chính vẫn là nước suối [1], vậy việc nghiên cứu xây dựng mô hình xử lý nước suối Tà Vải bằng công nghệ màng lọc kết hợp vật liệu lọc đa năng để cấp nước phục vụ cho sinh hoạt là vô cùng quan trọng, cấp thiết góp phần cải thiện chất lượng nguồn nước, chất lượng cuộc sống của người dân khu vực.

\section{Phương pháp nghiên cứu}

- Phương pháp thu thập số liệu: Thu thập, xử lý tài liệu liên quan để kế thừa có chọn lọc các kết quả nghiên cứu đã có.

- Phương pháp lấy mẫu nước sông, suối phân tích: Theo TCVN 6663-6 : 2008 [2]

Đánh giá 9 mẫu lấy vào tháng 07 (mùa mưa) năm 2017; Địa điểm lấy mẫu: khu vực thượng lưu suối Tà Vải, xã Kim Thạch, huyện Vị Xuyên tỉnh Hà Giang, Khu vực đập thủy lợi Tà vải, nước mặt tại trung đoàn 877 , nước sinh hoạt của người dân trong khu vực phường Ngọc Hà, xã Ngọc Đường, Thành phố Hà Giang, khu vực hạ lưu suối Tà Vải, các sông suối phụ cận, sông Niệm.

- Phương pháp xử lý số liệu: sử dụng phần mềm Excel 2010 để đánh giá độ tin cậy của các kết quả.

- Phương pháp phân tích mẫu nước: xác định các thông số chất lượng nước mặt và mẫu nước sau mô hình xử lý thực hiện theo hướng dẫn của các tiêu chuẩn quốc gia hoặc tiêu chuẩn phân tích tương ứng của các tổ chức quốc tế [2]. Mẫu nước được phân tích tại phòng phân tích môi trường phòng thí nghiệm (VILAS 995 - VIMCERTS 112) - Viện Kỹ thuật và Công nghệ Môi trường, kết quả được đối chứng tại Viện Hóa học Việt Nam. 


\section{Kết quả nghiên cứu}

\section{1. Đánh giá hiện trạng nước suối Tà Vải}

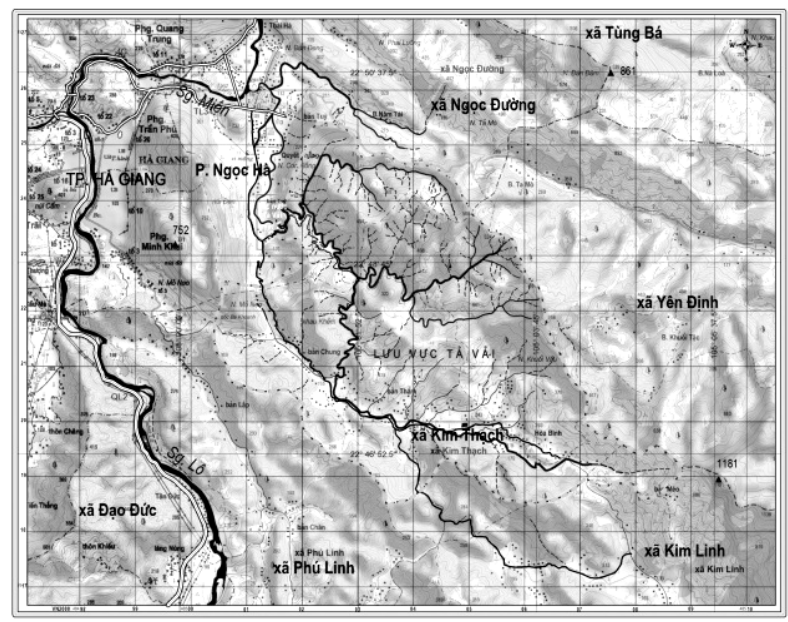

Hình 1. Vị trí lưu vục suối Tà Vải

Suối Tà Vài là một con suối chảy trong địa phận tỉnh Hà Giang, bắt nguồn từ huyện Vị Xuyên, chảy qua xã Kim Thạch, chảy vào thành phố Hà Giang, đi qua địa phận xã Ngọc Đường và Phường Ngọc Hà rồi đổ vào sông Niệm.

Suối Tà Vải là nguồn cung cấp chính cho sinh hoạt và hoạt động sản xuất nông nghiệp cho các khu dân cư hai bên bờ suối, doanh trại quân đội Trung đoàn 877 và Trường quân sự thuộc Bộ Chỉ huy quân sự tỉnh Hà Giang.

\section{Kết quả phân tích mẫu nước suối Tả Vải:}

Vị trí các điểm quan trắc:

- Mùa mưa xác định 09 điểm mẫu để phân tích như sau:

NM10: Suối Tà Vải, điểm đầu nguồn, gần Trường tiểu học Kim Thạch, Kim Thạch, Vị Xuyên, Hà Giang.

NM11: Suối Tà vải, điểm đầu nguồn, gần Trường tiểu học Kim Thạch, Kim Thạch, Vị Xuyên.

NM12: Suối Tà Vải, điểm hợp lưu đầu tiên phía trước đập.

NM13: Nhánh rẽ đầu tiên chảy vào suối Tà Vải.

NM14: Suối Tà Vải, giữa đập thủy lợi.

NM15: Suối Tả Vải, tại Bản Trang, xã Kim Thạch, huyện Vị Xuyên.

NM16: Suối Tả Vải, cửa xả tràn thân đập.

NM17: Suối Tà Vải, nhánh suối phía Tây Bắc dòng chính (nhánh thứ 2).

NM18: Suối Tả Vải, điểm hợp lưu thứ hai trước thân đập.

\section{Kết quả phân tích cho thấy}

Qua kết quả quan trắc chất lượng nước của suối Tà Vải cho thấy các chỉ số $\mathrm{BOD}_{5}, \mathrm{COD}$, TSS, các kim loại
$\mathrm{Fe}, \mathrm{Mn}$, các vi khuẩn như Coliforms hay E.Coli đều vượt quy chuẩn QCVN 08-MT:2015/BTNMT Quy chuẩn kỹ thuật quốc gia về nước mặt. Cụ thể như sau:

Chỉ số $\mathrm{BOD}_{5}$ vượt xa mức quy chuẩn QCVN 08MT:2015/BTNMT, mẫu lớn nhất là mẫu NM12 (26 $\mathrm{mg} / \mathrm{L})$ gấp 6 lần, mẫu nhỏ nhất là mẫu NM15 $(10,5 \mathrm{mg} / \mathrm{L})$ gấp 2,5 lần quy chuẩn. Trung bình tất cả các mẫu vào khoảng 15,5 tương đương gấp 4 lần quy chuẩn. Chỉ số COD vượt mức cho phép từ 2 đến 4 lần ( $\max \mathrm{COD}=45,8$ $\mathrm{mg} / \mathrm{l}, \min \mathrm{COD}=17 \mathrm{mg} / \mathrm{l}$, trung bình $\mathrm{COD}=28,3 \mathrm{mg} / 1$ trong khi quy chuẩn là $10 \mathrm{mg} / \mathrm{l})$. Hàm lượng chất rắn lơ lửng TSS vượt gấp nhiều lần so với quy chuẩn (Max TSS $=112 \mathrm{mg} / \mathrm{l}$, $\min$ TSS $=96 \mathrm{mg} / \mathrm{l}$, trung bình TSS $=108,6$ $\mathrm{mg} / \mathrm{l}$ trong khi quy chuẩn A1 là $20 \mathrm{mg} / \mathrm{l}$ ) [3].

Hàm lượng các kim loại như $\mathrm{Mn}$ và $\mathrm{Fe}$ của các mẫu vượt chỉ tiêu cho phép trong quy chuẩn (Max $\mathrm{Mn}=0,34$ mg/l tại vị trí mẫu NM05 - Suối Tả Vải, tại Bản Trang, xã Kim Thạch, huyện Vị Xuyên).

Chỉ số Coliforms hay E.Coli cũng đều vượt mức tại những vị trí suối Tả Vải, điểm hợp lưu thứ hai trước thân đập và tại mương thuỷ lợi sau thân đập, đây cũng là vấn đề dễ hiểu khi lượng bùn cát, cây cối... hợp chất hữu cơ được lắng đọng nhiều trong lòng đập chứa.

Qua kết quả phân tích chất lượng nước lưu vực suối Tà Vải, ta thấy chất lượng nước lưu vực suối Tà Vải đa số bị ô nhiễm, vì vậy muốn sử dụng nước suối Tà Vải để cấp nước cho sinh hoạt cần có biện pháp, công nghệ xử lý để xử lý, loại bỏ các chất ô nhiễm có trong nước suối.

\subsection{Công nghệ xử lý nước sông suối hiện đang áp dụng tại Việt Nam}

Hiện nay ở nước ta công nghệ xử lý nước sông suối để cấp cho nước sinh hoạt đang áp dụng phổ biến là công nghệ lắng lọc kết hợp Clo khử trùng.

Nước sông suối $\rightarrow$ Phèn nhôm, trợ keo tụ $\rightarrow$ Lắng $\rightarrow$ Clo khử trùng.

Nước sông suối sau khi đưa về hồ chứa sẽ được trộn thêm phèn nhôm và chất trợ keo tụ có tác dụng làm trong nước, các cặn lơ lửng sẽ được lắng đọng xuống đáy hồ, khi bơm nước đi sử dụng sẽ tiến hành châm Clo để khử trùng cho nước. Đây là công nghệ được sử dụng rộng rãi hiện nay tuy nhiên chất lượng nước sau xử lý của công nghệ này không đảm bảo chất lượng tuyệt đối khi dùng cho sinh hoạt, các kim loại như Fe, As, Mn... có trong nước sẽ không được xử lý triệt để, ngoài ra việc sử dụng Clo để khử trùng sẽ gây cảm giác khó chụi, người dùng tiếp xúc lâu ngày dễ gặp các triệu chứng lâm sàng về đường hô hấp nhu: ho, khó thở, đau ngực, phù phổi... vì hàm lượng Clo dư trong quá trình xử lý rất nhiều. 
3.3. Tổng quan về màng lọc và vật liệu lọc đa năng trong xử lý nước

* Màng lọc

Trong xử lý nước ta có thể loại bỏ các tạp chất ra khỏi nước mà không cần sử dụng hóa chất nhờ sử dụng công nghệ màng lọc, các tạp chất khi đi qua màng sẽ bị màng giữ lại chỉ cho nước sạch đi qua. Các loại màng hiện nay đang được dùng trong xử lý nước là: Lọc màng micro (MF), lọc màng siêu lọc(UF), lọc màng Nano (NF) và lọc màng thẩm thấu ngược $(\mathrm{RO})$.

- Lọc màng micro (MF) : Lọc mirco (MF) là phương pháp lọc có thể loại bỏ được những hạt có kích thước mirco trở lên. Màng lọc MF có kích thước lỗ khoảng 0,1 đến $10,0 \mu \mathrm{m}$, có thể loại bỏ gần hoàn toàn các vi sinh vật và cặn lơ lửng, vì vậy nó cũng là một phương pháp tốt để khử khuẩn, công nghệ màng lọc MF đang được ứng dụng rộng rãi trong xử lý nước hiện nay.

- Lọc màng siêu lọc (UF): công nghệ lọc UF đang được sử dụng rộng rãi cho xử lý rất nhiều loại nước khác nhau, màng UF có khả năng giữ lại các hạt có khoảng khối lượng phân tử 300-500.000 dalton, kích thước hạt 10-1000 $\AA(0,001-0,1 \mu \mathrm{m})$. Màng có hiệu quả trong sản xuất nước tinh khiết, kết hợp với xử lý hóa học để loại bổ các kim loại trong nước.

- Lọc màng Nano (NF): Lọc Nano (NF) là một dạng lọc sử dụng màng tách loại chất tan dạng phân tử hoặc ion ở cấp độ kích thước nano mét. Màng NF thường được sử dụng để sản xuất nước mềm bởi vì nó có đặc điểm là loại bỏ tốt các cation có hóa trị hai ví dụ như canxi và magie gây độ cứng và các chất khác.

- Lọc màng thẩm thấu ngược (RO): Không giống những màng lọc thông thường khác, chỉ có thể loại bỏ chất rắn có kích thước đủ lớn, màng lọc thẩm thấu ngược (RO) là loại màng duy nhất có thể lọc loại bỏ được hầu hết các khoáng chất hòa tan, vi khuẩn, virus và tất cả các vi sinh khác có trong nước. Tuy nhiên trước hệ thống lọc RO phải kết hợp thêm những màng lọc khác để hạn chế sự tắc nghẽn màng do các tạp chất bám vào màng.

Qua nghiên cứu thấy rằng với các đặc trưng của nước sông suối nói chung và suối Tà Vải nói riêng thì màng lọc MF và UF là hai màng lọc phù hợp nhất để sử dụng xử lý các chất ô nhiễm có trong nước sông suối. Hai màng lọc này sẽ kết hợp với nhau, màng MF sẽ bổ trợ cho màng UF để công suất và hiệu quả xử lý tốt hơn.

\section{*Vật liệu lọc đa năng}

Là các vật liệu rắn có cấu trúc lỗ nhỏ, lỗ được hình thành bởi sự ghép nối của các tứ diện qua nguyên tử oxy chung. Được hoạt hóa ở nhiệt độ cao, có tính hấp phụ, hấp thụ, loại bỏ các kim loại nặng, các tạp chất hữu cơ là vật liệu an toàn trong quá trình xử lý cấp nước sinh hoạt và ăn uống.

Qua nghiên cứu thì thấy vật liệu lọc đa năng Zeonit Diatomit (ODM-2F) là phù hợp nhất để kết hợp với màng lọc để xử lý nước sông suối.

\section{4. Đề xuất mô hình xử lý nước suối Tà Vải bằng công nghệ màng lọc kết hợp vật liệu lọc đa năng}

* So đồ công nghệ (Hình 2)

Hình 2. So đồ công nghệ mô hình xư lý nuớc suối Tà Vải bằng công nghệ màng lọc kết hợp vật liệu lọc đa năng

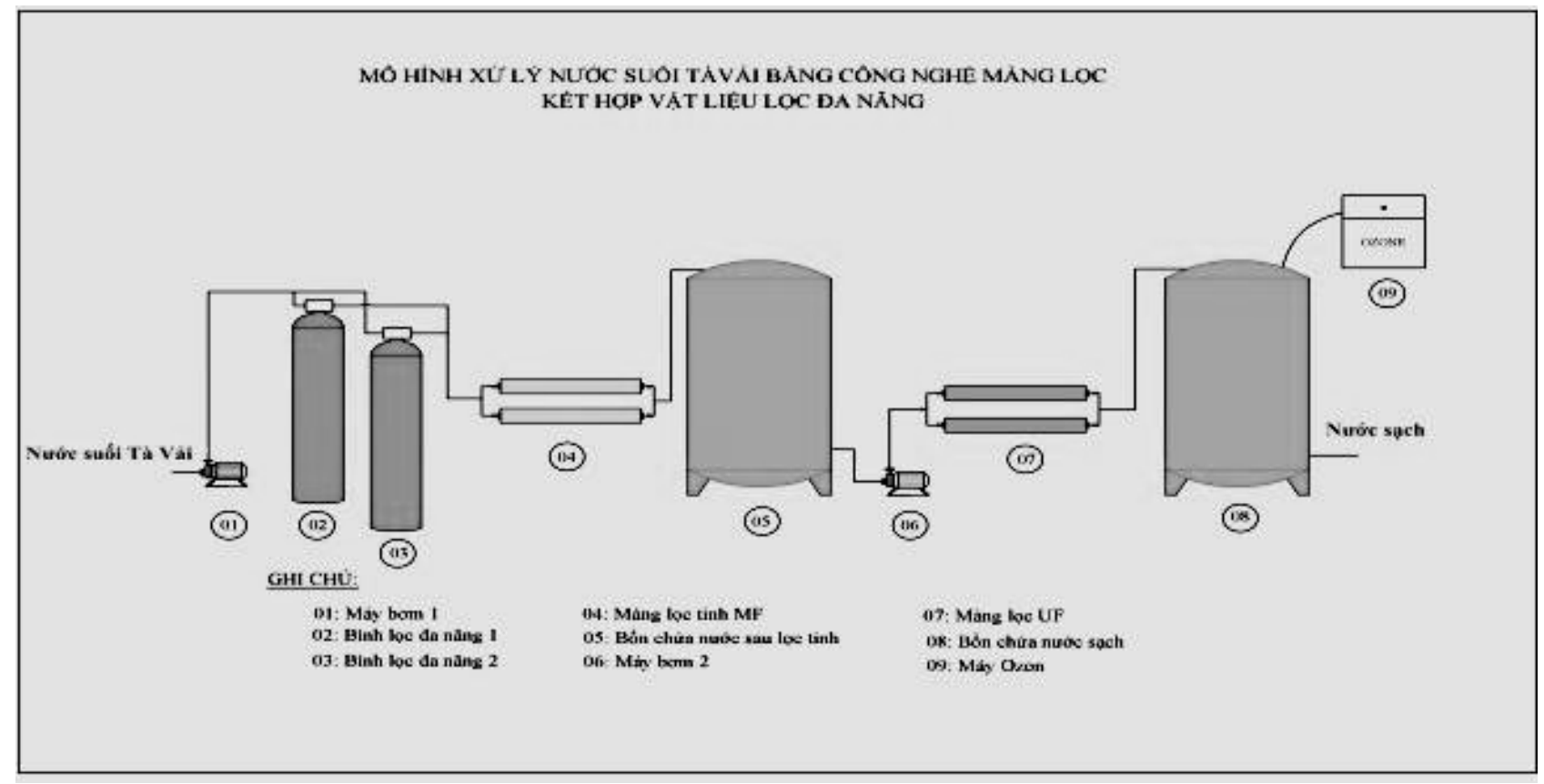




\section{* Thuyết minh công nghệ}

Nước suối Tà Vải qua đường ống về mô hình xử lý, tại đây nước được đẩy vào 2 hệ thống bình lọc đa năng chứa vật liệu lọc đa năng Zeonit - Diatomit (ODM-2F) và lớp cát đỡ lót phía dưới, tại đây vật liệu lọc đa năng Zeonit - Diatomit (ODM-2F) sẽ khử tạp chất hữu cơ và các chất ô nhiễm gốc nitơ, đồng thời giảm độ màu và làm trong nước. Nước sau xử lý ở giai đoạn này sẽ được đưa sang hệ thống màng lọc tinh MF. Sau một chu kỳ làm việc, hệ thống lọc vật liệu cần được sục rửa giúp các tạp chất bám vào vật liệu lọc di chuyển ngược lên phía trên bình lọc và xả bỏ ra ngoài, quy trình vận hành sục rửa hoàn toàn tự động theo cài đặt trên tủ điều khiển.

Nước sau lọc thô sẽ đẩy vào 2 bộ lọc tinh (còn gọi là màng tinh lọc, chất liệu polypropylene) được thiết kế với cấu hình dòng chảy từ ngoài vào trong (tạp chất, chất ô nhiễm được giữ lại bên ngoài màng và nước sạch được đẩy vào bên trong) tại đây màng sẽ giữ lại các tạp chất và chất ô nhiễm có kích thước lớn hơn lỗ màng và chỉ cho nước sạch cùng tạp chất có kích thước nhỏ hơn lỗ màng đi qua. Đầu ra của bộ lọc tinh có 2 nhánh: ống trung tâm là nước sạch, ống còn lại là nước xả chỉ mở định kỳ khi sục rửa ngược trong quá trình tẩy rửa màng. Nước sau quá trình này sẽ được đưa vào bồn chứa nước sau lọc tinh.

Nước sau lọc tinh sẽ được hai bơm tiếp áp hút nước từ bể chứa đẩy vào hệ lọc màng UF, tại đây dưới áp lực cao, các phân tử nước thẩm thấu qua màng UF, các thành phần chất ô nhiễm và virut có trong nước được giữ lại bên ngoài màng còn nước sạch được đẩy vào bên trong màng, đầu ra của hệ lọc màng UF cũng có 2 nhánh: ống trung tâm là nước sạch, ống còn lại là nước thải chứa các chất ô nhiễm. Nước sau quá trình này sẽ được đưa vào bồn chứa nước sạch.

Nước sau màng lọc UF sẽ được diệt khuẩn bằng máy khử trùng Ozon đảm bảo nước đạt tiêu chuẩn cho phép QCVN 02:2009/BYT Quy chuẩn kỹ thuật quốc gia về chất lượng nước sinh hoạt [4] để sử dụng vào mục đích cấp cho sinh hoạt.

Tất cả hoạt động của từng giai đoạn đều được thực hiện một cách tự động hóa theo tín hiệu của phao cơ, phao điện hay hệ thống đo online tự động.

\section{* Chất luợng nước sau xủ lý của mô hình công nghệ}

Sau khi mô hình lắp đặt xong tại phòng thí nghiệm Viện Kỹ thuật và Công nghệ môi trường, tiến hành lấy mẫu và phân tích mẫu nước sau khi được xử lý qua mô hình, cho thấy chất lượng nước đã đạt tiêu chuẩn QCVN
02:2009/BYT - Quy chuẩn Kỹ thuật quốc gia về chất lượng nước sinh hoạt, cụ thể như sau:

- Các chỉ số độ đục, độ cứng, clo dư đều ở mức rất thấp, thấp hơn 1 -2 lần so với quy chuẩn cho phép.

- Hàm lượng các kim loại $\mathrm{As}, \mathrm{Fe}, \mathrm{Mn}$ đều rất thấp, hàm lượng $\mathrm{As}$ và $\mathrm{Mn}$ không phát hiện, hàm lượng Fe thấp hơn $2-3$ lần so với quy chuẩn cho phép và so với mẫu trước khi xử lý.

- Các chỉ tiêu vi sinh vật Coliform và E.coli đều không phát hiện thấy trong mẫu nước sau xử lý, đảm bảo nước được tiệt trùng hoàn toàn.

- Hàm lượng $\mathrm{BOD}_{5}, \mathrm{COD}, \mathrm{TSS}$ đều giảm 5 - 6 lần so với chất lượng nước ban đầu.

\section{Kết luận}

Hiện nay nhiều khu vực vùng núi Tây Bắc nói chung và khu vực suối Tà Vải tỉnh Hà Giang nói riêng, nơi cơ sở vật chất còn nhiều thiếu thốn, khó khăn, người dân còn chưa được sử dụng nguồn nước đảm bảo chất lượng để sử dụng cho sinh hoạt. Việc nghiên cứu ra mô hình xử lý nước suối thành nước đạt tiêu chuẩn để cấp cho sinh hoạt của người dân nơi đây là hết sức quan trọng và ý nghĩa, qua nghiên cứu cho thấy công nghệ màng lọc kết hợp vật liệu lọc đa năng là phương pháp hiệu quả cho mô hình xử lý nước suối Tà Vải thành nước cấp cho sinh hoạt. Nước sau khi xử lý đạt QCVN 02:2009/BYT - Quy chuẩn kỹ thuật quốc gia về chất lượng nước sinh hoạt.

\section{Lò̀i cám ơn:}

- Nghiên cứu này được thực hiện trong khuôn khổ đề tài thuộc chương trình khoa học và công nghệ trọng điểm cấp nhà nước Giai đoạn 2013 - 2018 "Khoa học và Công nghệ phục vụ phát triển bền vững vùng Tây Bắc”, mã số đề tài KHCN-TB.15C/13-18.

- Các mô hình đã được thực hiện tại Phòng thí nghiệm của Viện kỹ thuật và Công nghệ Môi trường.

\section{TÀI LIỆU THAM KHẢO}

1. Báo cáo tình hình kinh tế xã hội của xã Ngọc Đường, phường Ngọc Hà, Tp. Hà Giang, 2016;

2. Lê Trình (1997), Quan trắc và kiểm soát ô nhiếm môi trương nước, $\mathrm{Nxb}$ Khoa học và Kỹ thuật, Hà Nội;

3. Tiêu chuẩn Quốc gia, quy chuẩn kỹ thuật Quốc gia QCVN 08-MT:2015/BTNMT, về nước thải sinh hoạt;

4. Tiêu chuẩn Quốc gia, quy chuẩn kỹ thuật Quốc gia QCVN 02:2009/BYT, về chất lượng nước sinh hoạt. 